\title{
ANTIBACTERIAL POTENCY OF AQUEOUS AND METHANOLIC EXTRACTS OF Diospyros mesiliformis LEAF AND STEM BARK
}

\author{
*Jamilu, H., Gambo, J.B. and Ocheme, J.J. \\ Department of Applied Biology Kaduna Polytechnic \\ Email: hadiza.jamilu123@gmail.com.08031901199
}

\begin{abstract}
Diospyros mespiliformis"Jackal berry" (also known as African ebony and by its Afrikaan name Jackal bessie). In hausa its called kanya, igi dudu (black wood) in Yoruba and Onye-oji (Black fellow) in igbo. It is widely used locally in treating various ailments such as fever, whooping cough, wounds, malaria, pheumonia, syphilis, leprosy and host of other ailment without proper scientific validation. This investigation is aimed at validating the scientific use of Diospyros mespiliformis leaf and stem bark using two solvents, methanol and aqueous. Phytochemical screening of the crude extracts revealed the presence of bioactive compounds such as saponins, tannins, alkaloids flavonoids, steroids, terpenoids and glycoside. The extracts were tested against Escherichia coli, Salmonella typhi and Staphylococcus aureus respectively. The antibacterial activity of the stem bark extracts revealed higher activity against E. coli, S.typhi and S. aureus than the leaf extracts. The mean range of zones of inhibition of stem bark at $100 \mathrm{mg} / \mathrm{ml}$ and $12.5 \mathrm{mg} / \mathrm{m} /$ varies between $19.29 \pm 3.82$ and $5.71 \pm 2.05$ while that of leaf extract ranges from $17.71 \pm 2.06$ and $5.43 \pm 1.13$ at $100 \mathrm{mg} / \mathrm{ml}$ and 12.5 respectively. Key words: Antibacterial, Phytochemicals, Diospyros mespiliformis, Minimum Inhibitory Concentration.
\end{abstract}

\section{INTRODUCTION}

Diospyros mespiliformis "Jackal berry" (also known as the African Ebony Kanya in Hausa, Igi dudu, Yoruba and Onye Oji, Igbo) is a large deciduous tree found mostly in Savannah of Africa. It is a tall tree that grows up to 25 meters in height. It has a dense evergreen canopy (Belemtougri et al., 2006). Diospyros mesipiliformis has been used in Traditional medical systems including Ayurveda, Chinese and Africa (Abdulrauf et al., 2000). Mature tree have dark grey fissured bark, an adult tree reaches an average of 4 to 6 meters in height, though occasionally trees reach 25 meters. The foliage is dense and dark green with elliptical leaves, which are often eaten by grazing animals such as elephants and buffalo. The tree flowers grows in the rainy season, the flowers are imperfect with genders on separate trees and are cream color. The female trees bears fruit in the dry season and these are eaten by many wild animals. They are oval shaped, yellow and about $20-30 \mathrm{~mm}$ in diameter with purple fruits when they are ripen. The tree like marula is favoured by the Bantu cultivated lands in order to harvest the fruit. The plant is widely used in parts of Africa and a number of chemical constituents of therapeutic importance have been isolated (Burkill, 2005). Diospyros mespiliformis is widely used as a folkloric remedies for the treatment of fever, malaria whopping cough etc, it has a large range of medicinal uses (El-Kamali, 2011).

A traditional food plant in Africa, the fruit has potential to improve nutrition. Diospyros mespiliformis has a fantastic mutualism and symbiotic network with many living organism from human beings to small insects. There is a complex ecological system revolving around this tree. It is one of the savannah giants that can live for more than 200 years (Quideau et al., 2012). This study aim at screening the stem bark and leaf extract of Diospyros mespiliformis for the presence of bioactive compounds as well as antibacterial potential of methanol and aqueous extract against Escherichia coli, Salmonella typhi and Staphylococcus aureus.

\section{MATERIAL AND METHODS}

Plant material

The plant Diospyros mespiliformis collected from Jibiya local government area of Katsina state, Nigeria in March 2018. It was authenticated at the Herbarium section of Department of Biological Science, Ahmadu Bello University, Zaria, with Voucher specimen number 02684 have been deposited for future references. 
Special Conference Edition, November, 2019 Processing of Plant Materials

The stem bark of Diospyros mespiliformis was washed with distilled water and shade dried. The dried material was powdered using mechanical method and resulting powder is sieved with sieve of $0.3 \mathrm{~mm}$ aperture size and stored in airtight container (El- Kamali, 2011).

\section{Extraction of Plant Material}

The powdered stem bark and leaf materials were subjected to successive solvent extraction using methanol and distilled water. 500 grams each of the powered plant materials were subjected to soxhlet extract $12-16$ hours with $1000 \mathrm{ml}$ of the various solvents. The extracts obtained were later kept for evaporation to remove the excessive solvents. These extracts were stored in a cool dry place for the analysis of the presence of preliminary phytochemicals and invitro antibacterial activities.

\section{Preliminary Phytochemical Analysis}

All the plant extracts were screened for the presence of bioactive compounds namely alkaloids, glycosides, saponins, phytosterols, tannins, flavonoids and terpenoids by using standard methods (Cuilel, 2014).

\section{Antibacterial activity test}

The antibacterial activities of the methanol and aqueous extracts were determined using E.coli, $S$. Typhi and $S$. aureus obtained from Yusuf Dantsoho memorial hospital Kaduna, all the bacterial isolates were checked for purity and maintained in slant of nutrient agar. $10 \mathrm{~g}$ of the extracts was weighed and dissolved in $10 \mathrm{ml}$ of DMSO to obtain a concentration of $100 \mathrm{mg} / \mathrm{ml}$. This was the initial concentration of the extracts used to determine the antimicrobial activities of the plant.

\section{Standardization of Inoculum}

Few colonies of the confirmed isolates were dispensed in normal saline to match the 0.5 McFarland standard for sensitivity test as described by NCCLS (1999).

Mueller Hinton agar was the growth medium used it was prepared according to the manufacturer's instruction, sterilized at $121^{\circ} \mathrm{C}$ for 12 minutes, poured in to the sterile dishes and allowed to cool and solidity. The sterilized medium was then seeded with $0.1 \mathrm{ml}$ of the standard inoculums of the test organisms, the inoculums was spread evenly over the surface of the medium by the use of a sterile swab. By the use of standard cork borer of $6 \mathrm{~mm}$ in diameter, a well was cut at the centre of each inoculated medium. $0.1 \mathrm{ml}$ of the solution of the extract at concentrations $100 \mathrm{mg} / \mathrm{ml} 50 \mathrm{mg} / \mathrm{ml}, 25 \mathrm{mg} / \mathrm{ml}$ and
$12.5 \mathrm{mg} / \mathrm{ml}$ were introduced into the well on the medium while $1 \mathrm{mg} / \mathrm{ml}$ of the standard, profloxacin was used as positive control. The inoculated medium was incubated for 24 hours at $37^{\circ} \mathrm{C}$, after which the plates were observed for the zones of inhibition of growth, the zone were measured with a transparent ruler and the results were recorded in millimeters $(\mathrm{mm})$.

\section{Determination of Minimum Inhibitory Concentration}

The minimum inhibitory concentration of each extract was determined using the broth dilution method. Mueller Hinton broth was prepared; $10 \mathrm{ml}$ was dispensed into test tubes and was sterilized at $121^{\circ} \mathrm{C}$ for 15 minutes, the broth was allowed to cool. McFarland standard turbidity scale number 0.5 was prepared to give turbid solution. Normal saline was also prepared, $10 \mathrm{ml}$ was dispensed into sterile test tubes and the microbe was inoculated and incubated at $37^{\circ} \mathrm{C}$ for six hours. Dilution of the test microbe was done using the normal saline until the turbidity matches that of the McFarland scale by visual comparison, at this point, the test tubes has a population density of $1.5 \times 10^{8} \mathrm{CFU} / \mathrm{ml}$. Two fold serial dilution of the extracts were done in the sterile broth to obtain the concentration of $100 \mathrm{mg} / \mathrm{ml}, 50 \mathrm{mg} / \mathrm{ml}, 25 \mathrm{mg} / \mathrm{ml}, 12.5 \mathrm{mg} / \mathrm{ml}$ and $6.25 \mathrm{mg} / \mathrm{ml}$. Haven obtained the different concentration of the extracts in the sterile broth, $0.5 \mathrm{ml}$ of the test microbes in the normal saline was then inoculated at the different concentrations, incubation was done at $37^{\circ} \mathrm{C}$ for 24hours after which the test tubes of the broth were observed for turbidity (Abba et al., 2016; El-Mahmood et al., 2018). The lowest concentration of the extracts in the broth which shows no turbidity was recorded as the minimum inhibitory concentration (Andrews, 2010).

\section{Determination of Minimum Bacterial Concentration}

The MBC was carried out to determine whether the test microbes were killed or only their growth was inhibited. Mueller Hinton was prepared, sterilized at $121^{\circ} \mathrm{C}$ for 15 minutes, poured into sterile petri dishes and was allowed to solidity. The contents of MIC in the serial dilution were then sub- cultured on to the prepared medium; incubation was made at $37^{\circ} \mathrm{C}$ for 24 hours after which the plates of the medium were observed for colony growth. MBC was the plates with the lowest concentration of extracts without colony growth (French, 2001). 
Special Conference Edition, November, 2019 RESULTS AND DISCUSSION

The phytochemical analysis of the crude extracts of methanol and aqueous stem bark and leaves extracts of Diospyros mespiliformis revealed the presence of tannins, saponins, glycosides, glycosides, alkaloids, flavounoids, steroids and terpenoids in all the extracts except anthraquione which was found to be absent in all except in methanol stem bark extract. The result agreed with the work of Yakubu and Mukar (2007). Flavonoids have been known to have antioxidant, antibacterial, antifungal and antiviral activity (Bors et al., 1990). Alkaloids are known for their pharmacological activities such as anti-bacterial and anti-fungal activities (Shagal et al., 2012). Saponins: are known for antibacterial activity against microorganisms, they also exhibit heamolytic activity upon injection into the blood stream as such it is advisable to administer it orally in medical application (Shagal et al., 2012).

Tannins are compounds that have the ability to react with protein to form stable water insoluble components. They act as detoxifying agents and as such they have ability to precipitate the protein on the cell wall of bacteria thereby inhibiting the growth of bacteria (Shagal et al., 2012). Tannins precipitate proteins of the wound , forming a protective layer on the wound, thus assisting in the arrest of bleeding and also used for wound, healings activity (Quideau et al., 2012). It is also used in the treatment of diarrhea as an effective astringent medicine in the small intestine. The result of the zone of inhibition as shown in Tables 3 - 4 shows that the methanolic stem bark extract had zone of inhibition of between $13-16 \mathrm{~mm}$ where as the aqueous stem bark extract had zone of inhibition of between $10-14 \mathrm{~mm}$ when compared to the standard ciprofloxacin, this explains that the activity of Diospyros mespiliformis is comparable to the standard hence, the plant can be used to treat various diseases caused by these selected organisms. Similarly the result of the zone of inhibition of the leaf extracts (Table 4 ) revealed that the methanolic leaf extract had zone of inhibition between $12-13 \mathrm{~mm}$ while the aqueous leaf extract had a value of $9-14 \mathrm{~mm}$. the standard drug had zone of inhibition between $15-19 \mathrm{~mm}$. The extracts of Diospyros mespiliformis can be substituted to the standard drugs.

The statistical analysis indicates that the difference between the zone of inhibition on stem bark differ significantly base on concentration $(p<0.05)$, it is also observed from the analysis that the zone of inhibition is significantly higher in the control and $100 \mathrm{mg} / \mathrm{ml}$ than in other level of concentration and it is found to be lower at $12.5 \mathrm{mg} / \mathrm{ml}$ and $25 \mathrm{mg} / \mathrm{ml}$ of concentration. The analysis also revealed that the difference between the zone of inhibition on leaf extracts differ significantly based on concentration $(p<0.05)$, from the analysis than the zone of inhibition is significantly higher in the control and $100 \mathrm{mg} / \mathrm{ml}$ than in other level of concentration with lowest at $12.5 \mathrm{mg} / \mathrm{ml}$ and $25 \mathrm{mg} / \mathrm{ml}$ level of concentration.

The result of the minimum inhibitory concentration (Table 6-7) revealed that the methanolic stem bark extract had MIC range of between 6.22 to $12.5 \mathrm{mg} / \mathrm{ml}$ whereas the aqueous stem bark extract had MIC of between 6.25 to $25 \mathrm{mg} / \mathrm{ml}$, the result shows that the stem bark extract had a high activity than the aqueous extract. Similarly, the MIC of the methanolic leaf extract and aqueous leaf extract as shown in table 5 showed MIC range of between 12.5 and $25 \mathrm{mg} / \mathrm{ml}$ while the aqueous leaf extract had MIC range of between $25 \mathrm{mg} / \mathrm{ml}$ to $50 \mathrm{mg} / \mathrm{ml}$ respectively. The result showed that the methanolic extract had better antibacterial activity than the aqueous extracts.

The minimum bactericidal concentration (MBC) is the lowest concentration that can kill the organism. The result of the MBC as shown in table 6 and 7 revealed that the methanolic stem bark extracts had MBC range of between 12.5 and $25 \mathrm{mg} / \mathrm{ml}$ where as the aqueous extract showed MBC of $50 \mathrm{mg} . \mathrm{ml}$ for all the organisms tested. The results of the methanolic leaf extract of Diospyros mespiliformis revealed an MBC of 25 and $50 \mathrm{mg} / \mathrm{ml}$ while aqueous leaf extract showed a range of $50 \mathrm{mg} / \mathrm{ml}$ to kill the tested organisms than the stem bark. It was deduced that stem bark extract have high antibacterial activity against the selected organisms than the leaf extract.

Table 1: Phytochemical characteristics of Diospyros mespiliformis

\begin{tabular}{llc}
\hline Crude extract & \multicolumn{2}{l}{ Percentage yield of each extract (\%) } \\
\cline { 2 - 3 } & Methanol & Aqueous \\
\hline Stem bark & 48.7 & 15.7 \\
Leaf & 10.63 & 6.60 \\
\hline
\end{tabular}


Special Conference Edition, November, 2019

Table 2: Phytochemical Characteristics of Stem Bark and leaf extracts of Diospyros mespiliformis

\begin{tabular}{lllll}
\hline $\begin{array}{l}\text { Bioactive } \\
\text { compound }\end{array}$ & $\begin{array}{l}\text { Leaf extract } \\
\text { Methanol }\end{array}$ & $\begin{array}{l}\text { Leaf extract } \\
\text { Aqueous }\end{array}$ & $\begin{array}{l}\text { Stem bark extract } \\
\text { Methanol }\end{array}$ & $\begin{array}{l}\text { Stem bark } \\
\text { Aqueous }\end{array}$ \\
\hline Tannins & + & + & + & + \\
Saponins & + & + & + & + \\
Alkaloids & + & + & + & + \\
Flavanoids & + & + & + & + \\
Glycosides & + & + & + & + \\
Anthraquinone & - & - & + & - \\
Steroids & + & + & + & + \\
\hline Key: Present $(+)$, Absent $(-)$ & &
\end{tabular}

Table 3:Zone of inhibition of the stem bark extracts of Diospyros mespiliformis

\begin{tabular}{|c|c|c|c|c|}
\hline \multicolumn{5}{|c|}{ Zone inhibition $(\mathrm{mm})$} \\
\hline Test organisms & $\begin{array}{l}\text { Methanol } \\
\text { stem bark }\end{array}$ & extract & $\begin{array}{l}\text { Aqueous extract Stem } \\
\text { bark }\end{array}$ & Ciprofloxacin (5ug/ml) \\
\hline E. coli & 13 & & 9 & 15 \\
\hline S. Typhi & 12 & & 11 & 16 \\
\hline S. aureus & 13 & & 14 & 19 \\
\hline
\end{tabular}

Table 4: Zone of inhibition of the leaf extracts of Diospyros mespiliformis

\begin{tabular}{|c|c|c|c|c|}
\hline \multirow[b]{2}{*}{ Test organisms } & \multicolumn{3}{|c|}{ Zone inhibition in ( $\mathrm{mm})$} & \multirow[b]{2}{*}{$\begin{array}{l}\text { Ciprofloxacin } \\
\text { (5ug/ml) }\end{array}$} \\
\hline & $\begin{array}{l}\text { Methanol extract } \\
\text { stem bark }\end{array}$ & $\begin{array}{l}\text { Aqueous } \\
\text { Stem bark }\end{array}$ & extract & \\
\hline E.coli & 16 & 12 & & 18 \\
\hline S. Typhi & 14 & 10 & & 16 \\
\hline S. aureus & 13 & 14 & & 19 \\
\hline
\end{tabular}

Table 5: Comparing difference in zone of inhibition of stem bark and leaf base on concentration level.

\begin{tabular}{lll}
\hline Concentration $\mathbf{( m g / m l )}$ & \multicolumn{1}{c}{ Stem bark } & \multicolumn{1}{c}{ Plant Part } \\
\cline { 2 - 3 } & \multicolumn{1}{c}{ Mean \pm S.D } \\
\cline { 2 - 3 } & & \multicolumn{1}{c}{ Mean \pm S.D } \\
\hline Control & $19.29+3.82^{\mathrm{c}}$ & $17.71 \pm 2.06^{\mathrm{c}}$ \\
100 & $15.71 \pm 4.27^{\mathrm{c}}$ & $15.00 \pm 6.16^{\mathrm{b}, \mathrm{c}}$ \\
50 & $10.86 \pm 4.26^{\mathrm{b}}$ & $12.29 \pm 2.87^{\mathrm{b}}$ \\
25 & $7.57 \pm 2.15^{\mathrm{a}, \mathrm{b}}$ & $8.43 \pm 1.90^{\mathrm{a}}$ \\
12.5 & $5.71 \pm 2.06^{\mathrm{a}}$ & $5.43 \pm 1.13^{\mathrm{a}}$ \\
\hline F-value & 18.603 & 15.391 \\
P-value & 0.000 & 0.000 \\
\hline Values are mean \pm Standard deviation, Value with different superscript across a column have \\
significant difference
\end{tabular}


Special Conference Edition, November, 2019

Table 6: Minimum Inhibitory Concentration of stem bark extracts of Diospyros mespiliformis

\begin{tabular}{llllll}
\hline \multicolumn{5}{c}{ Methanol stem bark extract (Aqueous) } \\
\hline Test organisms & 100 & 50 & 25 & 12.5 & 6.75 \\
E. coli & $-(-)$ & $-(-)$ & $-(-)$ & $-(+)$ & $+(+)$ \\
S. Typhi & $-(-)$ & $-(-)$ & $-(-)$ & $-(+)$ & $-(+)$ \\
S.aureus & $-(-)$ & $-(-)$ & $-(-)$ & $-(+)$ & $+(+)$ \\
\hline
\end{tabular}

Key: - no growth, + growth

Table 7: Minimum Inhibitory Concentration of leaf extracts of Diospyros mespiliformis Methanol leaf extract (Aqueous)

$$
\text { Concentration }(\mathrm{mg} / \mathrm{ml})
$$

\begin{tabular}{llllll}
\hline Test & 100 & 50 & 25 & 12.5 & 6.75 \\
organisms & & $-(-)$ & $-(+)$ & $-(+)$ & $+(+)$ \\
E. Coli & - & - & $-(-)$ & $+(+)$ & $+(+)$ \\
S. Typhi & - & $-(-)$ & $-(+)$ & $-(+)$ & $+(+)$ \\
S. aureus & - & $-(+)$ &
\end{tabular}

Key: - no growth, + growth

Table 8: Minimum Bacteriacidal Concentration of stem bark extracts of Diospyros mespiliformis

\section{Methanol stem bark extract (Aqueous)}

\begin{tabular}{llllll} 
Test organisms & \multicolumn{6}{c}{ Concentration $(\mathrm{mg} / \mathrm{ml})$} \\
\hline & 100 & 50 & 25 & 12.5 & 6.75 \\
E.coli & $-(-)$ & $+(+)$ & $-(-)$ & $-(-)$ & $-(-)$ \\
S.typhi & $-(-)$ & $+(+)$ & $-(-)$ & $-(+)$ & $-(-)$ \\
S.aureus & $-(-)$ & $+(+)$ & $+(-)$ & $-(-)$ & $-(-)$ \\
\hline
\end{tabular}

Key: - no growth

+ growth

Table 9: Minimum Bacteriacidal Concentration of leaf extracts of Diospyros mespiliformis Methanol leaf extract (Aqueous)

Test organisms Concentration $(\mathrm{mg} / \mathrm{ml})$

$\begin{array}{llllll} & 100 & 50 & 25 & 12.5 & 6.75 \\ \text { E. coli } & -(-) & +(+) & -(-) & -(-) & -(-) \\ \text { S. Typhi } & +(+) & +(-) & -(-) & -(-) & -(-) \\ \text { S. aureus } & -(+) & +(+) & -(-) & -(-) & -(-)\end{array}$

\section{CONCLUSION}

The study showed that Diospyros mespiliformis leaf and stem bark could serve as potent antibacterial in ethnomedicinal sources. Treatment of typhoid, malaria, syphilis, leprosy

\section{REFERENCES}

Abba, A., Agunu, A., Abubakar, A., Abubakar, U.S. and Jajere, M.U. (2016). Phytochemical Screening and Antiproliferative effects of methanol extract of stem bark of Diospyros etc. Phytochemical content of the plant were confirmed to contain tannins, saponins, flavonoids, steroids, glycosides, however no anthraquinone detected in the plant.

mespiliformis against Guinea corn (Sorghum Bicolor) seeds. Journal of Pure and Applied Science; 9 (1): 1-5

Abdulrauf, F. and Naveed M.(2000). Phytochemical and Pharmacological evaluation of aerial parts of plants. 
Special Conference Edition, November, 2019

Journal of Pharmacy and Pharmacology, 2 (2) 015-020.

Andrews, J.M. (2010). Determination of Minimum Inhibitory Concentration. Journal of Antimicrobial Chemotherapy, 48 (11): 5-16

Belemtougri, R.G., Constantin, B., Cognar, C., Raynond, G. and Sawadog, L. (2006). Effects of two medicinal plants, Psidiumguajava L (Myrtaceae) and Diospyros mespiliforms L (Ebenaceae) Leaf Extract of Rate skeletal muscles cells in primary culture. Journal of Zhejiang University (1):56-63.

Burkill, H.M. (2005). The useful plant of West Tropical Africa: 5 (1); 5-6.

Bors W, Heller W, Michel C, Saran M. (1990) flavonoids as antioxidants. Determination of Radical- Scavanging efficiencies in: Parker L, Glazer AN, Methods in enzymology. Vol 186 Pp 343355.

Cuilel, I. (2014). Methodology for the Analysis of vegetable Drugs; chemical industries Branch, division industrial operations, UNIDO, Romoalo; 26-27.

El-Kamali, H.H. (2011).Diospyros mespiliformis hochst ex A.D.C PROTA (Plant Resources of Tropical Africa/Ressources Vegetales de I' Afrique Tropicale). Wageningen Netherlands.

El-Mahmood, A.M., Doughari, J.H. and Ladan, N. (2008): Antimicrobial Screening of Stem Bark, seed extracts of vitelliriaparadixa against some Enteric Pathogenic Microorganisms. African Journal Pharmacology; 2:89-94
French, G.L. (2001). Bactericidal Agents in the Treatment of MRSA Infection- The potential role of Reptomycin. Journal Antimicrobial Chemotherapy; 58 (6): 1107-17

Muktar, M.D. and Tukur, A. (2000).Antimicrobial activity of extracts of Pistiastitatiotes. Journal Experimental biology 1(1): 51$60)$.

NCCLS (1999) performance standard of the antimicrobial susceptibility testing national committee for clinical laboratory approved standard M 100 - 59

Quideau, S., Varadinova, T., Karagiozova, D., Jourdes, M. and Pardon, P, (2012). Main structural and sterechemical aspects of the ant herpetic activity of nonalydoxyterphenoly-containing Lglycoside ellagitannins. Chemical Biodivers. 1: 247-258

Shagal, M.H. Kubmarawa, D. and Alim, H. (2012). Preliminary phytochemical investigation and antimicrobial evaluation of roots, stem-bark and leaves extracts of Diospyros mespiliformis. International Research Journal of Biochemistry and Bioinformatic, 2 (1); 011-015.

Sofowora, A (1993). Medicinal plant and traditional medicine in Africa spectrum Books Ltd Ibadan, Nigeria. P.289

Yakubu, A.L. and Muktar, M.D (2007). Photochemical in invitro antimicrobial activity of some phytochemical fraction of plants. Journal medicinal plants respiratory, 5: 2470-2475. 